\title{
The Threat from Without
}

\author{
An Examination of Defensive Ethnic Folklore
}

By Lassi Saressalo

Folklorists and scholars of comparative religion at the University of Turku have, by means of field work, been collecting material on Lapp folklore and contemporary folk belief ever since the 1960s (Saressalo 1981, 100-105). The present author also had a chance to take part in this work in the early days of his research career. One of the most exciting types of narrative material encountered in Lapp communities, and at the same time one of the most heterogeneous in its themes, comprised recollections, stereotype legends and tales that had already become anecdotes about a supranormal being called a staalo. Subsequent analysis of the field material at the university and comparison with earlier information on Lapp folk belief revealed that the narrative material was merely, 'disjointed material only loosely connected with the older and more genuine' staalo tradition. This 'true' staalo tradition was mostly to be found in older folkloristic literature, fairytale and legend indexes and anthologies. We came across the staalo tradition of Talvadas, the village around which our field work centred, as disconnected variants from which we could only guess at the existence of an old corpus of tradition, for the tradition had virtually died out. But even this encounter with the old folk motifs aroused this young researcher's interest and raised the question of what this folk material really was.

In his article "Lappalainen kansanrunous" (On the Folklore of the Lapps) T. I. Itkonen says that the most important being in the Lapp belief tradition is the staalo. He also mentions that this element of the tradition represents the very essence of all that is Lappish in the corpus of Lapp belief tradition (Itkonen 1963, 550 ff.). Having subsequently gone through Lapp folklore material in various folklore archives, I would agree with a later claim made by Itkonen - that in most cases the folklore we have been accustomed to regarding as Lapp in fact consists of local, regional or social variants or Lapp ethnic ecotypes of international or rather supranational folklore motifs. But we may find in the staalo tradition, uneven, confused and unclear though it is, certain basic elements that seem to be specifically Lappish.

The study of folklore has long been interested in this particular item of 
Lapp folklore; it has been the subject of dozens of articles, though views have concentrated on two distinct points of reference. Research has shown the Lapps' staalo as a being reflecting historical contacts "mellan samegrupper och gamla vikingar och röfvare som satte sig ner i ensliga skogstrakter och oroade Lapparne", as Lars L. Læstadius wrote to his friend Jacob Fellman (Fellman 1906, 160f.). This historical explanation enjoyed the support of such members of the older generation of staalo interpreters as Friis, Qvigstad and Sandberg (Friis 1871; Qvigstad \& Sandberg 1887). The greatest step in the analysis of the contacts and conflicts between Lapp communities and outsiders and their reflection in the staalo tradition has perhaps been taken by the Swede, Rolf Kjellström. Drawing on both oral tradition and the results of archaeological-ethnological research he has proved that the main phenomena of at least the western staalo tradition are tied up with the historically verifiable conflict between the Lapp communities dependent for their livelihood on the wild deer and the Viking-age hunters pushing northwards into the fells (Kjellström 1976). Kjellström's view also incorporates interpretations of certain staalo motifs from the eastern Lapp area. These feature a large, bearded man who, clad in furs, armed with a knife and accompanied by a dog, comes into physical contact with the Lapps in his fight for existence. The idea points straight to the Birkarlar, Russians, Karelians, Finns and Kvens who fought among themselves for possession of the territories inhabited by the Lapps from the Middle Ages onwards, the Lapps always being subordinated to the stronger parties. Kjellström's explanation has been supported most recently by Erich Kasten in his ethnohistorical research (Kasten 1983, $23 \mathrm{ff}$.). The second explanation seeks its interpretation via the universal explanations of mythology and folklore. Scholars have seen in the staalo the basic elements of arctic religions which have in the narrative process of tradition turned phenomena of an assumed original Lapp religion into more stereotyped narrative figures, confusing them with popular figures in different genres of neighbouring cultures (see Itkonen 1946, $87 \mathrm{f}$.). In this way, it is possible to view the staalo tradition as a phenomenological ecotype, Lappishness being represented only by the concept itself, to which the motifs brought by cultural contacts have been attracted.

A third explanation has also been put forward. The staalo has been sought in man himself, the motifs interpreted via the premises of psychoanalysis, chiefly by means of evolutionary theory of the mind, arriving at the profound mysteries of the human soul in the interpretation of motifs. This developing research approach is represented by Eliel Lagercrantz (Lagercrantz 1950). The staalo seems to be a sufficiently exciting and versatile phenomenon to produce more and more interpretation models. It 
will never be fully analysed, and there will always be room for creative imagination.

My own starting point in the interpretation of the staalo is modest. It is not my intention to seek a new explanatory model for the origin of the phenomenon, nor to cast doubt on the views already put forward. I simply intend to try to explain why the staalo tradition is in fact still alive, why such a belief, admittedly in weakening form, still exists in rational Lapp society.

My title for this article uses the concept 'defensive ethnic folklore'. The meaning of folklore itself hardly needs further explanation. But the meaning of ethnic folklore is already a broader question in need of more precise definition, especially since we are dealing with such a heterogeneous culture as Lapp culture as a whole. The view that the Lapps all embrace a homogeneous overall culture is of course out of date. The Lapps may be divided on ecological, economic, regional, linguistic and social grounds into a number of component cultures each with their own history, their own ethnically coloured identity and their own symbol system (Saressalo 1982, 59-64). For this reason the study of Lapp culture in general should return to local investigations, analyse the specific features of local cultures, seek local ethnic populations and only then attempt broader cultural generalisations. The researcher is faced with this situation when attempting to specify the Lapp image, the Lapp identity from within, esoterically. If, on the other hand, he seeks an overall image from without, by placing Lapp culture at a distance and viewing it as part of, say, North European culture, his point of reference is different. In this case analysis starts with the features that make Lapp culture "as a whole" different from other cultures. What is it that unites the Lapps but distinguishes them from others? The result is certain fundamental cultural elements that are "proto-Lappish" or which Lapp culture has "ethnicised", adapted to its own use and accepted as its own symbols. These common Lapp symbols are few in number, but they are all the more forceful and ones which the entire heterogeneous group has for cultural or minority policy reasons been able to accept as common (Mosli 1983, 21).

And we, as representatives of other cultures, have at the same time accepted these elements as Lappish. This strategy of exoteric Lapp identity symbols has also been exploited by the Lapp movement in the fight for its cultural existence, though it has at the same time to some extent had to generalise phenomena from different component cultures in ethnicising its symbolism. Such ethnicity symbols are language, costume, the weighting of the occupational structure, the 'joiku' singing tradition, the tendency towards organisation, marked external cultural features, but there may also 
be basic values deep in the world of tradition that can only be understood by someone living within that culture. The ethnic symbolism at this level comes out in e.g. oral tradition and its hidden meanings.

Of greatest importance in ethnic folklore are the recognised and unrecognised elements that are used when founding identity on tradition. For the aim of ethnic identification is to note and know the cultural features that a) connect me with people like me and b) separate me from people who are not like me. If and when we understand ethnic identity as being the same as the concept 'social belonging', the features separating 'us' from 'them' become more significant than those 'we' have in common. This constant process of comparing 'us' with 'them' calls for stereotype images of ourselves and others. These images are assimilated by anyone growing up within a culture at the enculturation stage, the stereotypes are there ready in the collective tradition of the community, they are neither appraised nor doubted. The same collective tradition also provides ready behaviour models for possible confrontation with others, ready examples of how members of the community have handled similar cultural clashes before. And tradition also provides ready models and images of 'others', even though they may never be needed. Any group that wishes to remain in existence culturally must be prepared in advance for cultural confrontation with others. Without a strong ethnocentric value charge of this kind, aimed at the preservation of cohesion, the group will disintegrate under the pressure of the constant cultural assimilation process (Saressalo 1983, 195-201).

Every group and each of its members thus needs an opponent, a contact partner in order to identify itself. This opponent may be fact or fiction. We can all name both concrete and fictive comparisons in our own culture. What about the Lapps?

If we examine Lapp cultures, different groups separately, we see that there are so many of these contact partners used in the identification process that they do not constitute a clear, uniform system for use in comparison. The coast Lapps have a completely different contact and comparison world from, say, the Pite Lapps. The Skolts meet totally different people from the Southern Lapps, the cattle breeders have a different comparative system from the reindeer breeders. This being the case, it is necessary to choose some other means of comparing these groups. In order to find some uniform basis for cultural comparison in different situations, it is possible to take as the point of reference the oral tradition, folklore and its main themes and basic ideas, and in this way to find a solution - a sufficiently unconcrete object for constructing a comparison on a different basis. This point of reference is a situation with only two components: us (who know ourselves) and them, anyone not one of us 
but a sufficiently general concept to provide potential for local variations.

The ethnocentric values of ethnic folklore provide a model for this generalising comparison. 'They' are a potential danger, are unknown, strange, a threat from beyond the fells. They are sufficiently common for the group's ethnic feeling. It is here that we find tradition, folk tales, describing the community's traditional enemies, describing the threat from without, engendering preconceived ideas, conflicts and even war.

There are no periods of former greatness in the history of Lapp culture. The Lapps have never had an empire, they have never conquered others' territory, they have never engaged in systematic warfare against other peoples. For this reason Lapp tradition lacks an offensive ethnic folklore proper with emphasis on aggression, power, violence, heroism and an acceptance of the ideology of subordinating others. On the contrary.

Lapp folklore is familiar with a tradition in which strangers are always threatening the Lapps' existence, plundering their territories, burning and destroying. The Lapp has always had to fight against alien powers, to give in or to outwit the great and powerful enemy. We are well familiar with the international legends of foes and their Lapp ecotypes, the "tšudi" stories (Rausmaa 1973, 91-104). This genre is still living narrative tradition in, for example, place names. But are these place names and the legends explaining them the reason why this tradition has been preserved? Or must we look for the explanation for the preservation of these folk motifs in the present day, now that 'their' economic strivings and desire to get 'back to nature' are encroaching on the everyday world of the Lapps? It is here that defensive tradition steps in to reinforce the Lapps' identity.

Maybe we will no longer come across the crafty Lapp who leads his enemy to his death, who sends him headlong over the cliff, who leaves him to die on a deserted island or who drives him into the foaming rapids (Qvigstad 1925, 54f.) But we may find the same basic attitudes and the same goal in telling toady's legends, anecdotes and jokes. Today the enemy are southerners, those in authority, researchers, tourists and women. In the actual telling situation we find the same tendency, the same mood as in the old stereotype legends of foes: the motifs constitute a certain type of tradition element approaching a myth, repeated in a socially ordered context, that gives the narrating community a chance to feel secure and independent in its own sphere.

We see the same basic set-up in the staalo tradition. Regardless of whether the staalo stories are historically justifiable, of whether they are fictive or mythical, they undoubtedly tell of a fundamental conflict between a Lapp and 'others'. That the staalo motifs are as heterogeneous as they 
are, that they occur in so many genres, that the staalo has attracted so many different beings representing an outside threat proves that the tradition is one of ancient standing. That we find the staalo tradition only among the Lapp population of Fenno-Scandia again proves that it has had and still has a major function in the defensive ethnic tradition of the Lapps.

The fact that the staalo itself is such an inexplicable and vague phenomenon is mainly a problem for researchers and really has nothing to do with the esoteric identity image of the narrative community. The man-eater, devil or giant in the fairytale may, in a different context and in another area, become a vague, threatening being, a ghost sent to plague a Lapp, a zealous wrestler in human shape, mighty and strong. In the next case, the staalo may be a fictive defender of norms who frightens children, who metes out punishment if the yard is not swept in time for Christmas. It may be just a presentiment of something that exists beyond the safe area.

In the Lapp tradition the staalo represents an outside threat that cannot be directly concretised. If foes are regarded as concrete enemies that may be defeated in physical combat or that can be made to look ridiculous, a staalo is more mythical, more supranormal, more vague. One basic feature of the staalo tradition is that it only appears as one party to a conflict. The stories about the Lapp who succeeds in driving away a staalo threatening the community, to outwit the stupid giant or to kill him with his own weapon come close to the myth of the beginning of time when a Lapp managed to secure his existence and defend his community against an outside threat. Without the proto-Lapp battle against evil, the community would not have had a chance to exist, the right to live in its area, as the community does nowadays.

I began in the village of Talvadas on the river Teno, along the border between Finland and Norway, deep in the land of the Lapps. The material collected in the village contains a host of associations with commonly known fairytale tradition, general comments and beliefs on the existence of the staalo, its appearance and doings, and a threat to norms. The main staalo motif known in the village is, however, the story of the battle between a staalo and Stuorra-Jouni. In the world of the present-day narrator Jouni represents the historically recognisable but sufficiently remote proto-Lapp, who was a wild deer hunter and a good story-teller. The legends about Stuorra-Jouni appear in several different variants. One of them tells how someone from Varanger sent a staalo to attack Jouni. In keeping with the structural nuances that are a vital part of the story, Jouni nevertheless manages to kill the staalo and thus to save himself and his community. That the sender came from Varanger is no wonder: for it was to Varanger that people went for their annual shopping and fishing, and it 
was here that they met 'others'. Another Stuorra-Jouni variant tells how he met a staalo on Ailigas fell, the most notable local landmark. Battle commences in accordance with the established ritual pattern, but the staalo manages to escape, it comes down Ailigas on skis so that only its ski tracks remain. And these tracks are still there, to remind you that one of the first people in the region was victorious in battle, drove the menacing staalo away and thus secured the rights and safety of the Lapp community at Talvadas, on the river Teno. Herein lies, to my mind, the fundamental message of the staalo tradition.

\section{Bibliography}

Fellman, J. 1906. Anteckningar under min vistelse i Lappmarken 2. Helsingfors.

Friis, J. A. 1871. Lappisk Mythologi, Eventyr og Folkesagn. Christiania.

Itkonen, T. I. 1946. Heidnische Religion und späterer Aberglaube bei den finnischen Lappen. (Mémoires de la Société Finno-Ougrienne 87.) Helsinki.

- 1963. Lappalainen kansanrunous. Suomen kirjallisuus 1. Keuruu.

Kasten, E. 1983. Kulturwandel bei den Samen. Berlin.

Kjellström, R. 1976. Är traditionerna om stalo historiskt grundade? Fataburen.

Lagercrantz, E. 1950. Entwicklungspsychologische Analyse lappischer Folklore. (FF Communications 138.) Helsinki.

Mosli, J. H. 1983. Samiske næringsintressers plass i samfunnsplanlegging. Diedut 1.

Qvigstad J. 1925. Lappische Märchen- und Sagenvarianten. (FF Communications 60.) Helsinki.

Qvigstad, J. \& Sandberg, G. 1887. Lappiske eventyr og folkesagn. Kristiania.

Rausmaa, P.-L. 1973. A catalogue of historical and local legends in the folklore archives of the Finnish Literature Society. Nordic Institute of Folklore publications 3. Turku.

Saressalo, L. 1981. Tiefenforschung in einem samischen (lappischen) Dorf. Fabula 22.

- 1982. Talvadaksen kylän etnohistoriallinen kehitys. Turun yliopisto, kulttuurien tutkimuksen laitos. Folkloristiikan tutkimuksia 1 . Turku.

- 1983. Om etniska stereotyper. Folk og ressurser i nord. Trondheim. 